\title{
Use of Biogas as Energy Source: A Review
}

\author{
Vivek Koshta $^{1 *}$, Himanshu R. Patel ${ }^{1}$, Anil R. Chaudhari ${ }^{1}$, B.P. Shah ${ }^{2}$ and B.M. Patel \\ ${ }^{1}$ Dairy Engineering Department, Mansinhbhai Institute of Dairy \& Food Technology \\ (MIDFT), Mehsana (Gujarat-India) \\ ${ }^{2}$ S.M.C. College of Dairy Science, Anand Agricultural University, Anand (Gujarat-India) and \\ visiting Professor MIDFT, Mehsana-384002, India
}

*Corresponding author

\section{A B S T R A C T}

\begin{tabular}{|c|}
\hline Keywords \\
\hline $\begin{array}{l}\text { Biogas, } \\
\text { Methane, Combined } \\
\text { heat and power } \\
\text { generation (CHP) }\end{array}$ \\
\hline Article Info \\
\hline $\begin{array}{l}\text { Accepted: } \\
\text { 12 January } 2019 \\
\text { Available Online: } \\
\text { 10 February } 2019\end{array}$ \\
\hline
\end{tabular}

\section{Keywords}

Biogas

Methane, Combined

generation $(\mathrm{CHP})$

\section{Introduction}

Anaerobic digestion is the process of decomposition of organic material by a microbial population that lives in an oxygen free environment. Biogas obtained as an end product of this process mostly consists of up to $65 \%$ methane $\left(\mathrm{CH}_{4}\right)$ and carbon dioxide $\left(\mathrm{CO}_{2}\right) 30-40 \%$ by volume with small quantities of hydrogen sulfide $\left(\mathrm{H}_{2} \mathrm{~S}\right)$ and hydrogen $\left(\mathrm{H}_{2}\right)$ of potential energy source. Anaerobic digestion is carried out in four stages viz. hydrolysis, acedogenesis, acetogenesis and methanogenesis; by a consortia of bacteria working together to convert organic matter into gas and inorganic constituents (O'Leary and Walsh 1995; Gerardi, 2003; Ostream, 2004; Mc-Carty, 1964).

Calorific value of one cubic meter of the biogas is equal to 6 kilowatt hour or equal with half liter of diesel oil (Purwono et al., 2013). The quantity of biogas produced from the waste depends upon the percentage conversion of volatile solids to gas. Each pound of volatile solids digestion will produce approximately 5.62 cubic feet of 
methane. Each cubic feet of methane contains 1000 kilo joules of energy. Hence, each pound of volatile solids converted will produce 5620 kilo joules of energy $(1.6 \mathrm{kWh})$. At 35 percent conversion efficiency, each pound of volatile solids while digested will produce $0.58 \mathrm{kWh}$ of energy. Thus, the conversion efficiency is important during various anaerobic processes (Burke, 2001).

The rate and efficiency of the anaerobic digestion process is controlled by the type of waste being digested, its concentration, temperature, presence of toxic materials, $\mathrm{pH}$ and alkalinity, hydraulic retention time, solids retention time, ratio of food to microorganisms, rate of digester loading, and the rate at which toxic end products of digestion are removed.

EU is the world leader in biogas electricity production, with more than $10 \mathrm{GW}$ installed and a number of 17,400 biogas plants, in comparison to the global biogas capacity of $15 \mathrm{GW}$ in the year 2015 (Scarlat, 2018). The total biogas production in India is 2.07 billion $\mathrm{m}^{3} /$ year in the year 2017. This is quite low compared to its potential, which is estimated to be in the range of $29-48$ billion $\mathrm{m}^{3} /$ year (Mittal et al., 2018)

When biogas displaces fossil fuels from energy production and transport, a reduction of emissions of $\mathrm{CO}_{2}, \mathrm{CH}_{4}$ and $\mathrm{N}_{2} \mathrm{O}$ will mitigate the global warming (Seadi, 2008). This mitigation can be registered and can be used for generation of carbon credits as well. One carbon credit is equivalent to one tone of carbon di-oxide reduction attributed to one Carbon Emission Reduction (CER) unit. Carbon trading can be done as Biogas can be used in several ways as energy source. Biogas has multi function and can be used in a variety of applications (Alexopoulos, 2012). It can be directly used for house hold cooking, combined heat and power generation (CHP), bio-fuel, fuel cells, or it can be upgraded and fed into natural gas grids.

\section{Purification of biogas}

The typical composition of biogas obtained from various sources and the natural gas is shown in the Table 1 given below.

Biogas usually contains approx. 60-70 \% of methane on average, which can be further increased upto $85-90 \%$ by its purification. Purification process involves removal of the constituents of biogas like $\mathrm{CO}_{2}, \mathrm{H}_{2} \mathrm{~S}$, halogenated hydrocarbon removal, siloxane removal, etc. (Monnet, 2003) and it is necessary to purify biogas before its use (Alexopoulos, 2012) as the presence of $\mathrm{H}_{2} \mathrm{~S}$, $\mathrm{CO}_{2}$ and $\mathrm{H}_{2} \mathrm{O}$ makes the biogas corrosive in nature. However, biogas can be directly used for house hold cooking purposes.

Removal of $\mathrm{CO}_{2}$ enhances the energy of the gas either to reach vehicle fuel standard or natural quality gas. Mainly, four different methods are commercially used to remove $\mathrm{CO}_{2}$ from biogas: water scrubbing, polyethylene glycol scrubbing, carbon molecular sieves and membranes separation (Monnet, 2003). Baciocchi et al., (2013) employed Alkali absorption with Regeneration (AwR) technique that allows to capture and store the separated $\mathrm{CO}_{2}$.

The water vapour content in the biogas can be removed by membrane separation processes, in which purified biogas can be collected in retentate and water vapour portion can be collected as a permeate. Meireles et al., (2018) illustrated the potential of hybrid polysaccharide membranes prepared by crosslinking of glycerol with a trimethoxysilane (silica precursor) for dehydration of biogas. These membranes showed barrier properties to methane while exhibiting high water permeability and higher 
selectivity for methane content in biogas. Polysaccharide class of polymer is nontoxic, biocompatible, biodegradable and renewable. It consists of repeating units of mono- or disaccharides linked by glycosidic bonds that form either linear or branched structures.

As discussed earlier, hydrogen sulphide must be removed from the biogas in order to avoid corrosion which can be done by several means and the most common methods are: air/oxygen dosing to digester biogas, iron chloride dosing to digester slurry, iron oxide, activated carbon, water scrubbing and $\mathrm{NaOH}$ scrubbing. Biological desulphurization of biogas can be performed by micro-organisms. Most of the sulphide oxidizing microorganisms belongs to the family of Thiobacillus and it is essential to add stoichiometric amounts of oxygen to the biogas (Monnet, 2003).

Halogenated hydrocarbons cause corrosion in the CHP engines and therefore, the manufacturers specify maximum limits of halogenated carbons in biogas. They can be removed using pressurized tube exchanger filled with specific activated carbon. Small molecules like $\mathrm{CH}_{4}, \mathrm{O}_{2}$, and $\mathrm{N}_{2}$ pass through while larger molecules are absorbed (Monnet, 2003).

Vacuum swing Adsorption (VSA) technology with 13x Zeolite can be effectively used to remove the impurities of volatile organic compounds like siloxanes, $\mathrm{CO}_{2}$ and $\mathrm{H}_{2} \mathrm{~S}$ (Paolini et al., 2018, Bareili et al., 2018).

Biogas composition may have organic silicon compounds which can cause severe damages to CHP engines. They can be removed by absorption on a liquid medium with a mixture of hydrocarbons compounds which absorbs the silicon compounds. The absorbent can be regenerated by heating and desorption.

\section{Utilization of biogas}

\section{Renewable energy sources for house hold cooking}

The biogas can be used for household purposes in rural areas for cooking purposes. Small biogas reactors can be managed at household level in remote areas and the biogas produced could be utilized for household cooking. Zhu et al., (2010) reported the biogas technology development and the status of comprehensive utilization of biogas in rural areas of Qinzhou, China. Qi et al., (2012) carried out inventory analysis for the household biogas system in Gongcheng, China. Similar measures of using biogas as renewable energy source has been reported in the villages of Indonesia (Purwono, 2013). Raha (2010) reported the use of biogas to promote clean and efficient energy cooking in sections of Assam, India.

\section{Bio-refinery systems}

Integrated production of biofuels (biogas, bioethanol and biodiesel) alongside with food and raw materials for industry, known as the concept of bio-refineries, is one of the important research area today, where biogas provides process energy for liquid biofuel production and uses the effluent materials of the other processes as feedstock for anaerobic digestion. The integrated biorefinery concept is expected to offer a number of advantages related to energy efficiency, economic performance and reduction of GHG emissions (Seadi, 2008).

\section{Combined heat and power (CHP) generation}

CHP generation is a standard utilisation of biogas from anaerobic digestion in many countries with a developed biogas sector, as it is considered a very efficient utilisation for 
energy production (Whiting and Azapagic, 2014). Biogas is drained and dried prior to its CHP conversion. Most gas engines have maximum limits for the content of hydrogen sulphide, halogenated hydrocarbons and siloxanes in biogas, therefore, purified biogas should be used for this purpose. An engine based CHP power plant has an efficiency of up to $90 \%$ and produces $35 \%$ electricity and $65 \%$ heat (Seadi, 2008).

The most common types of CHP plants are block type thermal power plants (BTTP) with combustion motors that are coupled to a generator. Generators usually have a speed of $1500 \mathrm{rpm}$ (rotations per minute) in order to make it compatible with the grid frequency. Motors can be Gas-Otto, Gas-Diesel or GasPilot Injection engines. Both, Gas-diesel and Gas-Otto engines are operating without ignition oil, according to the Otto principle. The difference between these engines is only the compression. The produced electricity from biogas can be used for working of electrical equipment such as pumps, control systems and stirrers.

\section{Biogas micro-turbines}

Biogas can be used as a fuel in a micro gas turbine or burner and can be used in a hybrid solar tower system offering a solution for waste treatment of agricultural and animal residues (Alexopoulos, 2012). Micro gas turbines are comprised of a single shaft on which the compressor, the turbine and the generator are fixed. The turbine propels the air and biogas mixture to the compressor. The air is pressed into a combustion chamber at high pressure and mixed with biogas (Kipyegon, 2011). The air-biogas mixture is burnt causing an increase in temperature and the expansion of the gas mixture. The hot gases are released through a turbine, which is connected to the electricity generator. The electric capacity of micro-turbines is typically below $200 \mathrm{kWe}$ (kilowatt-electric). The cost of biogas micro-turbines is high and the research and development work in this area is therefore aiming cost reduction for future models. The working principle of biogas based micro-turbine is shown in the Figure 1 given below.

\section{Biogas in fuel cells}

The methane contained in the biogas can also be used as a fuel for fuel cells. Fuel cells produce DC electricity by combusting fuel in presence of oxygen (from the air) in an electrochemical reaction and are used for electric power generation. There is no intermediate process which first converts fuel into mechanical energy or heat, therefore, fuel cells have extremely low carbon emissions. Fuel cells operate like a battery but, unlike a battery, it does not run down or require charging. Thus, it produces energy in the form of electricity and heat as long as fuel is supplied. In a first step fuel is converted to $\mathrm{H}_{2}$ which is then converted to direct electric current. The by-products of this electrochemical reaction are water and $\mathrm{CO}_{2}$. The conversion of electrochemical energy into electricity is expected to exceed $50 \%$. There are few different technologies but phosphoric acid fuel cells are commercialized. A number of power plants are operating in Japan and USA with a practical electrical efficiency of $41 \%$.

There are various types of fuel cell suitable for biogas, named according to the type of electrolyte used. The common examples are PEM -The Polymer-Electrolyte-Membrane (PEM) fuel cell, Phosphoric Acid Fuel Cell (PAFC), Molten Carbonate Fuel Cell (MCFC), Solid Oxide Fuel Cell (SOFC) etc. They can be low (AFC, PEM), medium (PAFC) or high temperature fuel cells (MCFC, SOFC). The choice of the fuel cell type depends on the gaseous fuel used and the 
heat utilization (Seadi, 2008; Monnet, 2003). Bareilli et al., (2018) used a zeolite mixture with copper ions as an adsorbent for $\mathrm{H}_{2} \mathrm{~S}$ removal from biogas, to obtain a de-sulfurized fuel which was further used in molten carbonate fuel cell systems (Fig. 2).

\section{Biogas as vehicle fuel}

Utilization of biogas in the transport sector is a technology with great potential and with important socio-economic benefits. The biogas is stored at 200 to $250 \mathrm{bar}$, in pressure vessels, made of steel or aluminum composite materials. Heavy duty vehicles can be converted to run on methane gas only, but in some cases dual fuel engines (hybrid engines) are used. A dual fuel engine may work as a diesel injection system in which a small amount of diesel is injected inside the compression chamber to ignite the gas. Dual fuel engines (hybrid type) require lesser engine development and maintain the same drive ability as a diesel vehicle. However, carbon emission values are not as low as for the corresponding specially built gas vehicles and the engine technology remains a compromise between spark ignition and diesel engine. Upgraded biogas (biomethane) is considered to have the highest potential as vehicle fuel, even when compared to other biofuels.

Table.1 Proximate composition of biogas obtained from various sources and natural gas

\begin{tabular}{|c|c|c|c|}
\hline Type of gas & $\begin{array}{c}\text { Biogas 1 } \\
\text { Household waste }\end{array}$ & $\begin{array}{c}\text { Biogas 2 } \\
\text { Agrifood industry }\end{array}$ & Natural gas \\
\hline $\begin{array}{c}\text { Composition } \\
\text { (\%vol by vol) }\end{array}$ & $60 \% \mathrm{CH}_{4}$ & $68 \% \mathrm{CH}_{4}$ & $97.0 \% \mathrm{CH}_{4}$ \\
& $33 \% \mathrm{CO}_{2}$ & $26 \% \mathrm{CO}_{2}$ & $2.2 \% \mathrm{C}_{2}$ \\
& $1 \% \mathrm{~N}_{2}$ & $1 \% \mathrm{~N}_{2}$ & $0.3 \% \mathrm{C}_{3}$ \\
& $0 \% \mathrm{O}_{2}$ & $0 \% \mathrm{O}_{2}$ & $0.1 \% \mathrm{C}_{4}+$ \\
\hline
\end{tabular}

Source: (http://www.biogas-renewable-energy.info/biogas_composition.html)

Fig.1 Working principle of Biogas based Micro-turbine (Source: Prasad and Rintala, 2013)

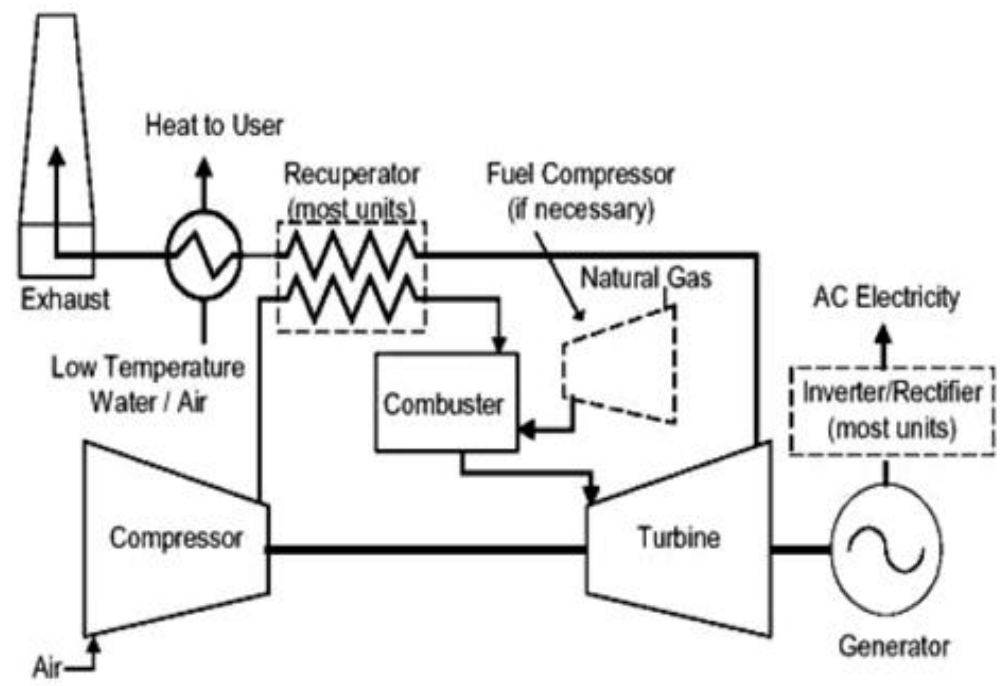


Fig.2 A simplified fuel cell (Source: US Department of Energy, office of Energy Efficiency and Renewable Energy)

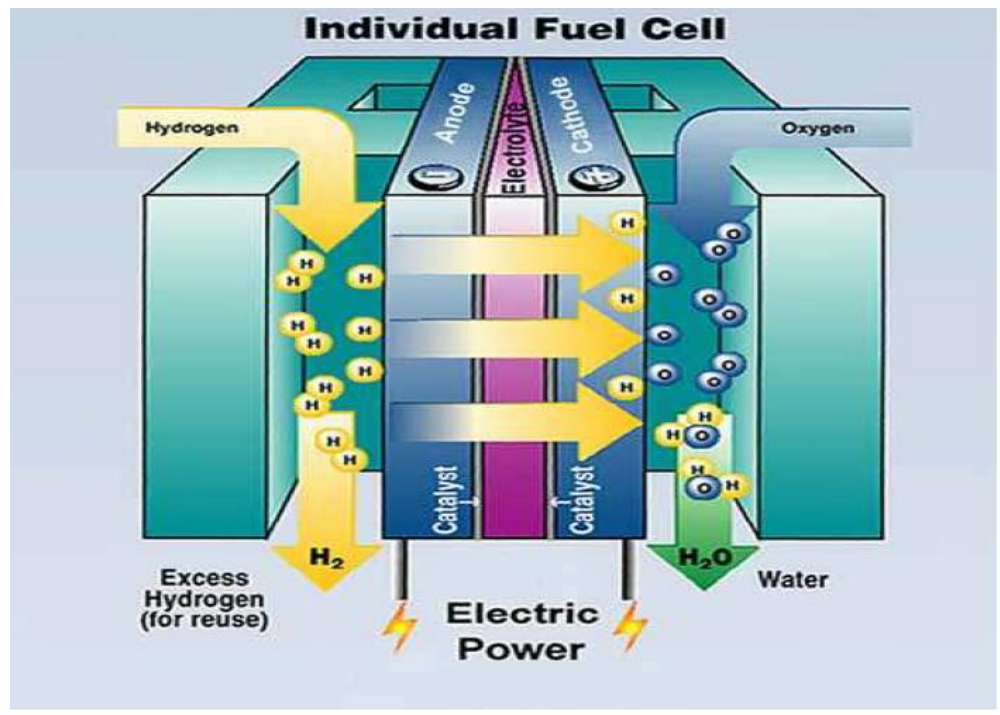

\section{Biomethane for grid injection}

Upgraded biogas (biomethane) can be injected and distributed through the natural gas grid, after it has been compressed to the pipeline pressure. Grid injection means that the biogas plant combined with a small CHP unit for the process energy or a biogas burner. The gas transmission system is the main component of the gas grid, transporting large volumes of gas at high pressure. The pressure in the system is created using high-powered compression plants. These compressors ensure that there is sufficient pressure in the gas system to deliver gas to all parts of the network to meet demand and maintain safe gas pressure levels in the whole network. The gas entering the system must be injected with odourant so that leakages can be detected and reported. There are several benefits of using gas grid for distribution of biomethane. A major advantage is that the grid connects the production site of biomethane, and can be easily distributed in short routes to the customers. It is also possible to increase the biogas production at a remote site (CER, 2013).
In conclusion, the world has recognized the importance of utilization of renewable energy sources. Biogas has emerged as an important alternative in this area. It has acquired its place in a number of applications like household cooking, CHP, Biogas grid, biofuel, etc. Its utilization has increased with the time and can be adopted in many sector of economy. It can play an important role in especially in rural areas of our country. However, its production and utilization is quite low as compared to its potential which may be due to the negligence of waste management system. Waste management system has to be upgraded for achieving its full potential.

\section{References}

Alexopoulos S. (2012). Biogas Systems: Basics, Biogas Multifunction, Principle of Fermentation and Hybrid Application with a Solar Tower for the Treatment of Waste Animal Manure. Journal of Engineering Science and TechnologyReview 5: (4) 48 -55 Special Issue on Renewable Energy Systems.

Baciocchi R, Carnevale E, Costa G, Lombardi L., Olivieri T, Paradisi A, Zanchi L, 
Zingaretti D. (2013). Pilot-scale investigation of an innovative process for biogas upgrading with $\mathrm{CO}_{2}$ capture and storage. Energy Procedia, 37: 60266034.

Barelli L, Bidini G., Micoli L., and Sisani E., (2018). 13X Ex-Cu zeolite performance characterization towards $\mathrm{H} 2 \mathrm{~S}$ removal for biogas use in molten carbonate fuel cells. Energy, 160:44-53.

Burke D.A. (2001). Dairy Waste Anaerobic Digestion Handbook. Environmental Energy Company.

CER. (2013) Biogas Injection into the Natural Gas Grid. Commission for Energy Regulation, The Exchange, Dublin. Available online at https://www.cru.ie/wpcontent/uploads/2013/07/cer13209biogas-injection-consultation-paper.pdf.

Gerardi M. H. (2003). The microbiology of anaerobic digesters. Published by John Wiley \& Sons. Kipyegon, B.I., (2011). Biogas Use in Power Generation (Dissertation, University of Nairobi). Mc-Carty P. 1. (1964). Anaerobic Waste Treatment Fundamentals. Public Works, 95(9):107 112.

Meireles I.T., Fraga S.C. Huertas R.M., Brazinha C., Coelhoso I.M., Crespo J.G. (2018). Evaluation of hybrid polysaccharide membranes for gas dehydration using on-line mass spectrometry. Journal of Membrane Science, 562: 1-8.

Mittal S., Ahlgren E. O., Shukla P.R. (2018) Barriers to biogas dissemination in India: A review. Energy Policy. 112: 361-370. https://doi.org/10.1016/j.enpol.2017.10.02 7.

Monnet F. (2003). An introduction to Anaerobic Digestion of Organic Wastes. Remmade Scotland. 48 p. Available online at www.biogasmax.co.uk as on dated 14-05-14.
O'Leary Phillip R. and Walsh Patrick W. (1995). Decision maker's guide to solid waste management - Vol. II. Published by the University of Wisconsin.

Ostrem K. (2004). Greening waste: anaerobic digestion for treating the organic fraction of municipal solid wastes. M.S. Thesis. Department of Earth and Environmental Engineering. Fu Foundation of School of Engineering and Applied Science, Columbia University

Paolini V, Petracchini F, Guerreiro E and Bencini A. (2015). Biogas cleaning and upgrading with natural zeolites from tuffs. Environmental Technology 37(11):1-33. DOI: $10.1080 / 09593330$.2015.1118557.

Prasad K. and Rintala J. (2013) Generation of heat and power from biogas for stationary applications: boilers, gas engines and turbines, combined heat and power (CHP) plants and fuel cells. Chapter 17. The Biogas Handbook - Science, Production and Applications. Published by Woodhead Publishing Series in Energy, 404-427.

Purwono B., Suyanta and Rahbini. (2013). Biogas digester as an alternative energy strategy in the marginal villages in Indonesia. Proceedings of International Conference on Sustainable Energy Engineering and Application, 2012. Energy Procedia, 32: 136 - 144.

Qi J, Chen B., Chen W., Chu X.. (2012). Inventory analysis for a household biogas system. Proceedings of 18th Biennial Conference of International Society for Ecological Modelling. Procedia Environmental Sciences 13 (2012) 1902 1906.

Raha D., Mahanta P., Clarke M.L. (2014). The implementation of decentralized biogas plants in Assam, NE India: The impact and effectiveness of the National Biogas and Manure Management Programme. Energy Policy, 68: 80-91.

Scarlat N. (2018) Biogas: Developments and perspectives in Europe. Renewable 
Energy. 129A: 457-472 https://doi.org/10.1016/j.renene.2018.03.0 06.

Seadi, T (2008). Biogas Handbook. University of Southern Denmark, Esbjerg. 118 p. Available online at www.lemvigbiogas.com as on 14/05/14.

Soares P.I.P , Echeverria C., Baptista A.C., Joao C.F.C., Fernandes S.N., Almeida A.P.C., Silva J.C., Godinho M.H. and Borges J.P. (2017). Hybrid polysaccharide-based systems for biomedical applications. Ch.4. Hybrid
Polymer Composite Materials. 107-149. https://doi.org/10.1016/B978-0-08100785-3.00004-8.

Whiting A. and Azapagic A. (2014). Life cycle environmental impacts of generating electricity and heat from biogas produced by anaerobic digestion. Energy, Pp. 1-13. Article in Press.

Zhu Z., Liang O.S., Lan H.C. (2010). Problems and Solutions Based on Comprehensive Utilization of Biogas. Energy Procedia, 5: 42-47.

\section{How to cite this article:}

Vivek Koshta, Himanshu R. Patel, Anil R. Chaudhari, B.P. Shah and Patel, B.M. 2019. Use of Biogas as Energy Source: A Review. Int.J.Curr.Microbiol.App.Sci. 8(02): 1540-1547. doi: https://doi.org/10.20546/ijcmas.2019.802.180 